http://kitaibelia.unideb.hu/

ISSN 2064-4507 (Online) • ISSN 1219-9672 (Print)

(C) Department of Botany, University of Debrecen, Hungary

26(2): 199-206.; 2021

DOI: $10.17542 /$ kit.26.199

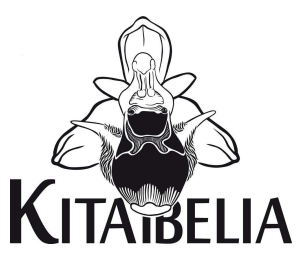

\title{
Új adventív faj Magyarország flórájában: az útifülevelú kígyószisz (Echium plantagineum)
}

\author{
CSECSERITS Anikó1* , JAKAB Gusztáv² \& RÉDEI Tamás ${ }^{1}$ \\ (1) Ökológiai Kutatóközpont, Ökológiai és Botanikai Intézet, H-2163, Vácrátót, Alkotmány u. 2-4.; \\ *csecserits.aniko@ecolres.hu \\ (2) Magyar Agrár és Élettudományi Egyetem, Környezettudományi Intézet, Vízgazdálkodási és Klímaadaptációs \\ Tanszék, H-2100, Gödöllő, Páter Károly utca 1.

\section{The purple viper's bugloss (Echium plantagineum), a new adventive species for Hungary}

\begin{abstract}
Following global trends, the number of newly established alien plant species is increasing in Hungary. Not only professional scientists but also citizens could contribute to the discovery and documentation of new occurrences. One of the first records of the purple viper's bugloss (Echium plantagineum L.) in Hungary originate from an online group dealing with wild plant species identification. This species is native in Western Mediterranean countries, and is introduced to other continents. In Australia, it is a well-spread, largely problematic invasive species, and it might show similar tendencies in Hungary as well. In order to acquaint the wider public with this species, we present its morphology, phenology and other characteristics and provide a possible inlay in the Hungarian identification key.
\end{abstract}

Keywords: alien species, Boraginaceae, citizen science, neophyte species

Összefoglalás - A világon mindenütt, így hazánkban is folyamatosan nő az újonnan megjelenő nem őshonos növényfajok száma. Az új megjelenések felfedezésében, dokumentálásában nemcsak a hivatásos kutatók vehetnek részt, hanem nagy szerepe lehet a civileknek is. Az útifúlevelú kígyószisz (Echium plantagineum L.) egyik első hazai adata is egy internetes, növényhatározással foglalkozó csoportban került elő. A faj a nyugat-mediterrán országokban őshonos, de más földrészekre is eljutott már. Ausztráliában elterjedt, jelentős problémát okozó inváziós fajnak számít, ezért mindenképpen indokolt a faj alaposabb megismerése és hazai terjedésének figyelemmel kísérése. Annak érdekében, hogy minél szélesebb körben ismerté váljon a faj, röviden bemutatjuk morfológiai, fenológiai és egyéb tulajdonságait és javaslatot teszünk a határozókulcsba való beillesztésre.

Kulcsszavak: Boraginaceae, civil kutatás, idegenhonos faj, neofiton

\section{Bevezetés}

Az ember valószínúleg évezredek óta szerepet játszik a növények terjedésében, de az utóbbi pár évszázadban a globális kereskedelem és közlekedés kialakulásával és megerősödésével ez a szerep nagyságrendekkel megnőtt (HuLme 2009, SEEBENS et al. 2017). Emellett az ember által okozott klímaváltozás is előmozdítja a növényfajok új területeken való megjelenését és tartós megtelepedését (EssL et al. 2019). A két hatás eredménye, hogy a világon mindenütt folyamatosan nő a flórában újonnan megjelenő idegenhonos növényfajok száma (SEEBENS et al. 2015) - így van ez hazánkban is (pl. TAKÁcs et al. 2020, WIRTH et al. 2020). A folyamat megállítására kevés lehetőség van, ugyanakkor fontos a dokumentálása és a megjelenő fajok meg- 
ismerése, hogy a későbbi kezelésükre vonatkozóan tudományosan megalapozott ajánlásokat lehessen tenni.

Az új fajok megtalálásában a hivatásos kutatók mellett a természetjáróknak, érdeklődőknek, civileknek is jelentős szerepük lehet. Hiszen mind a már itt élő, mind az újonnan megjelenő fajok aktuális előfordulásának, terjedésének nyomon követése nagy idő- és erőforrásigényű feladat, amely munkához a civilek - leginkább a könnyen felismerhető fajok esetén nagyban hozzájárulhatnak. A bevonás történhet felülről kezdeményezve, online felületet teremtve az adatok közlésének és kezelésének (pl. Vadonleső [1], Herptérkép [2], Magyarország Flóratérképezési Adatbázisa [3]), de történhet spontán módon is, például a különböző, interneten működő, tematikus közösségi csoportokon keresztül.

Alábbiakban egy olyan jövevényfaj, az Echium plantagineum L. megtalálásának körülményeit és tulajdonságait szeretnénk bemutatni, melynek előfordulásaira egy internetes csoportban hívták fel a figyelmet. Az Echium plantagineum első alkalmi kivadulási adatát FILARSZKY (1894) közölte Budapestről, Rákosmezőről, ahol is Filarszky leírása szerint dr. Procopp Jenő számos növény magját, többek közt az Echium plantagineum-ot (akkori nevén $E$. violaceum) elvetette, és a kinőtt példányok képesek voltak magot is érlelni és szaporodni. A MTM Növénytárában is szerepel egy herbáriumi példánya 1898-ból, sajnos hiányos adatokkal, mindössze annyi derül ki a lapról, hogy „Pest” a származási helye. Ezek alapján a fajt BALOGH et al. (2004) alkalmi neofitonnak sorolta be. Mivel ennél több, újabb előfordulási adatát nem találtuk, így a jelen cikkben közölt adat mindenképpen újdonság. A fajjal kapcsolatos külföldi inváziós tapasztalatok alapján megpróbáljuk megbecsülni a faj hazai terjedési és inváziós potenciálját is.

\section{A faj bemutatása}

Nevezéktan és taxonómia

Az érdeslevelűek (Boraginaceae) családjába tartozó kígyószisz (Echium) nemzetség mintegy 70 fajából hazánkban 3 faj őshonos (KIRÁLY 2009). Az újonnan talált Echium plantagineum L. leggyakoribb szinoním nevei: Echium lycopsis L. (1754), Echium maritimum Willd. (1798) sensu stricto, Echium murale Hill (1756) nom. illeg., Echium plantaginoides Roem. \& Schult. (1819), Echium sennenii Pau (1924), Echium violaceum L. (1767) (Euro+Med [5]). Angol neve: purple viper's bugloss, Paterson's curse, vagy purple echium (USDA [4]). Javasolt magyar neve az útifúlevelü kígyószisz (BALOGH et al. 2004).

\section{Morfológiai jellemzés}

Az útifülevelű kígyószisz tőlevélrózsás téli egyéves növény. Általában 20-60 cm magasra nő, de elérheti a $2 \mathrm{~m}$-t is. Tőlevelei 1,5-10 cm szélesek, 5-20 cm hosszúak, tojásdad alakúak, nyelesek, oldalerei kiemelkedőek. Szárlevelei hosszúkás-lándzsásak, a legfelsők többé-kevésbé szíves vállúak. Egy egyeden egy vagy több virágzó szár is fejlődhet, melyek széles, terpedt habitust kölcsönöznek a növénynek (1. ábra). A virága a közönséges kígyósziszéhez hasonlít, de ahhoz képest a csésze rövidebb, 7-10 mm virágzáskor, míg a párta hosszabb, 18-30 mm és az 5 porzószálból csak 2 nyúlik túl a szirmokon (míg az előbbi fajnál 4 porzószál is kiáll) (2. ábra). A szirmok bíbor vagy kék színűek, ritkán halványabbak, rózsaszínűek. Magja nyár végén-ősszel csírázik, majd tőlevélrózsát fejleszt és így telel át. Áprilisban kezd el virágozni, eredeti elterjedési területén június közepére elvirágzik. Ausztráliában megfigyelték, hogy megfelelő mennyiségű csapadék esetén hosszan elnyújtott lehet a virágzása. Tőlevelei a virágzás végére nagyrész visszaszáradnak. Termése $4 \mathrm{db}$ 2-2,5 mm hosszú résztermésre széteső, makkocska (3. ábra), ezermagtömege 3,6-3,9 g (CABI [5], PIGGIN \& SHEPPARD 1995). Az általunk 
megtalált kőérberki populációban az ezermagtömege 2,28 g volt (Török P. személyes közlése). Tartós (legalább 6 évig túlélő) magbankot képez (PIGGIN \& SHEPPARD 1995, GRIGULIS et al. 2001).

\section{Elterjedési terület, invázió története}

Az Echium nemzetség számos faja inváziós viselkedést mutat, például a nálunk őshonos terjőke kígyószisz az Egyesült Államokban és Ausztráliában is inváziós faj (USDA [4]). Az Echium plantagineum őshazája valószínủleg a Földközi-tenger nyugati partvidékén (Spanyolországban, Portugáliában) volt, de mára az egész Mediterráneumban elterjedt. Hozzánk legközelebb Horvátországban és Szlovéniában fordul elő, és ezekben az országokban nem neofiton fajnak, hanem őshonosnak tartják (Euro+Med [6], Flora Croatica [7], JoGAN et al. 2001). Németországban, Franciaországban, Nagy-Britanniában, valamint Albániában szintén előfordul és őshonosnak tartják (Euro+Med [6], Barina Zoltán közlése), míg Csehországban alkalmi megtelepedőnek tekintik (PYŠEK et al. 2012).

Mára már számos más száraz vagy mediterrán éghajlatú területen is megjelent és özöngyommá vált. Meghonosodott Afrika déli részén (Kenya, Tanzánia, Zimbabwe, Dél-Afrika), Észak- és Dél-Amerikában (Argentína, Chile, Uruguay), Ausztráliában, valamint Új-Zélandon is (Holm et al. 1979, USDA [4]).

Ausztráliába először dísznövénynek vitték be. Feltételezések szerint egy Paterson nevű személy ültette elsőként a kertjében, a XIX. század második felében. Innen származik az egyik elterjedt angol neve is: Paterson's curse (PIGGIN \& SHEPPARD 1995). A növény hamar népszerű dísznövénnyé vált egész Dél-Ausztráliában, számos kertészet a szaporításával is foglalkozott (PIGGIN \& SHEPPARD 1995). Később kivadult és az európai telepesek által kialakított legelőkön és szántóföldeken az egyik legelterjedtebb gyommá vált az 1970-es, 1980-as évekre. Ekkor próbálkoztak először a visszaszorításával, de gazdálkodók egy csoportja ellenezte az irtását. Ugyanis, bár elnyomta a legelő állatok számára fontos növényfajokat, a méhészet számára jelentős nektárforrás volt. Az útifúlevelű kígyósziszt eredeti elterjedési területén, valamint Dél-Afrikában és Ausztráliában is mézelő növényként hasznosítják és kedvelik a belőle készülő világos színű, jóízủ méz miatt. Emellett a legelő állatok számára is táplálékul szolgálhat. Végül bíróság előtt mérlegelték az fajhoz köthető előnyöket és károkat, és a döntés értelmében engedélyezték a faj visszaszorítását. Így már el tudták kezdeni a faj elleni kiterjedtebb biológiai, vegyszeres és mechanikai védekezést. Továbbá ez a jogi eset végül fontos katalizátorává vált az ausztrál biológiai védekezéssel kapcsolatos szabályozás megalkotásának is, mely úttörő volt a maga idejében (Cullen \& Delfosse 1984, PIGGin \& SHEPPARD 1995, SHEPPARD \& SMYTH 2012).

\section{Termőhelyi viszonyok - környezeti igények}

Eredeti elterjedési területén az útifülevelű kígyószisz a fajgazdag mediterrán gyepekben, legelőkön fordul elő (Noy-MEIR et al. 1989; FERNÁNDEZ ALÉs et al. 1993). Leginkább a semleges vagy savanyú homoktalajokat kedveli, de számos más talajtípuson is képes megélni. Az újonnan meghódított területeken is alapvetően legelőkön fordul elő, de mivel a juh és szarvasmarha legeltetés Ausztráliában és Dél-Amerikában csak mintegy 200 éve terjedt el, ezért a legelők, mint másodlagos élőhelyek általában jóval fajszegényebbek. Ausztráliában gyakran olyan nem őshonos fajokkal él együtt, melyekkel az eredeti elterjedési területén is együtt élt, ami jórészt a hasonló élőhelyi igénnyel magyarázható (SмYTH et al. 1992, GRIGULIS et al. 2001). A legelőkön kívül tömeges lehet az utak mentén, mezsgyéken, egyéb ruderális területeken, de esetenként szántóföldeken is megjelenik pl. zab vagy lucerna vetésekben (CABI [5]). 
Ausztráliában az útifúlevelú kígyószisz leginkább ott tud tömeges lenni, ahol az éves csapadék $1270 \mathrm{~mm}$-nél kevesebb, a legmelegebb hónapban a csapadék több, mint $64 \mathrm{~mm}$, és ennek a hónapnak az átlaghőmérséklete $21,1-26,7{ }^{\circ} \mathrm{C}$ közt változik. Emellett előfordulási területén a leghidegebb hónapban az átlagos csapadék több, mint $25 \mathrm{~mm}$ és az átlag hőmérséklet 4,4-10 ${ }^{\circ} \mathrm{C}$ közt változik (MOORE 1967). Ugyanakkor a faj képes olyan területen is megélni, ahol a legmelegebb hónap ennél szárazabb, viszont a rövid nappalok és a túl magas hőmérséklet hatására elmaradhat a virágzása (PIGGIN \& SHEPPARD 1995).

\section{Életciklus}

Téli egyéves növényként alapvetően nyár végén-ősszel csírázik: nedvesség jelenlétében 12$40{ }^{\circ} \mathrm{C}$ közt képes a csírázásra, leginkább vagy állandóan meleg, vagy $15-40^{\circ} \mathrm{C}$-os éjjel-nappal változó hőmérséklet esetén (PIGGIN \& SHEPPARD 1995). Csírázásához nem igényel fényt. A tavaszi csírázást az alacsony téli hőmérséklet gátolja. Az érett magok mintegy 30\%-a kicsírázik általában az ősz végére, de jelentős mennyiségű nyár végi csapadék esetén akár a magok 50\%-a is csírázhat. A megmaradt magoknak kb. 30 \%-a csírázik ki évente, és a magok akár 10 évig is életképesek maradhatnak a talajban (GRIGULIS et al. 2001).

A kicsírázott növény a tél folyamán tőlevélrózsát fejleszt, majd tavasszal virágot hoz. A virágzás 2-5 hónapig is eltarthat, a vízellátástól függően: száraz körülmények közt rövidebb lehet. A tőlevelek a virágzás vége felé rendszerint elszáradnak és a virágzás végén az egész növény elhal. Ritkán, bőséges vízellátás mellett akár nyár végéig is túlélhetnek az egyedek (BURDON et al. 1988, PIGGIN \& SHEPPARD, 1995).

Az egyes növényegyedek méretüktől függően nagyon eltérő mennyiségű magot hoznak: erősen legelt helyeken csak 15-60 db-ot, de megfelelő körülmények közt akár 10000 magot is hozhat egy növény (PIGGIN \& SHEPPARD 1995, SMYTH et al. 1997).

\section{Terjedés, inváziós utak}

Egyéves növényként magokkal terjed, igen változatos módon. A magjait számos állatfaj fogyasztja (pl. galambfajok) és tartaléknak gyưjti is (pl. hangyák). A magok terjedhetnek ektovagy endozoochor módon a legelő állatokkal, amit a makkocskák érdes felülete is segíthet. Emellett számos emberi tevékenység is szerepet játszik a terjedésében (pl. talajmozgatás, takarmány-szállítás, közlekedés) (PIGGIN \& SHEPPARD 1995).

Ausztráliában biológiai védekezéssel sikerült csökkenteni az állományát. A védekezés során hat, Európában őshonos rovarfaj egyedeit engedték szabadon, részletes előzetes vizsgálatok után. Végül 2 faj, a Mogulones larvatus nevü ormányosbogár és a Longitarsus echii nevű földibolha-faj populációja csökkentette jelentősen a kígyószisz állományokat (SHEA et al. 2000, SHEPPARD \& SMYTH 2012).

\section{Eredmények}

\section{Hazai előfordulások}

A fajt közel egy időben, két helyen is megtalálták. Az első említés egy Facebook-csoportban történt, ahol a fényképhez kapcsolódó megjegyzésként említésre került az időben korábban talált, szarvasi előfordulás is.

A szarvasi állomány a cikk második szerzőjének belterületi kertjéből [N 46,8743º, E 20,5389, KEF: 9189.1] került elő 2020. május 22-én, ahol gyomos, másodlagos pázsitban telepedett meg. Itt összesen 2 tő került elő. A példányok virágoztak és termést is érleltek. A pázsit közönséges, zavarástűrő fajokból áll, amit rendszeresen nyírnak: Lolium perenne, 
Glechoma hederacea, Stellaria media, Plantago major, Taraxacum officinale, Potentilla reptans, Veronica hederifolia s.l., Viola odorata, Polygonum aviculare. A két példány a virágzást követően be lett gyüjtve és Jakab Gusztáb herbáriumába lett elhelyezve dokumentálás céljából. 2021-es évben nem jelent meg újabb egyede a fajnak.

A budapesti adat nem a megszokott módon vált ismertté. A faj előfordulását igazoló fényképet Waldmann Katalin töltötte fel a Facebook „Növényhatározó természetjáróknak” nevű csoportjába 2020. június 5-én. Ezt követően június 21-én közös terepbejárást tartottunk a fotó készítésének helyszínén, Budapest 11. kerületben (Kőérberek) [N 47,4464 ${ }^{\circ}, \mathrm{E} 18,9864^{\circ}$, KEF: 8579.4], és dokumentáltuk az állományt.

A Puskapor utcában lévő társasház kertjében egy 2018 ősze és 2019 tavasza közt végzett csatorna-felújítás során máshonnan hozott, talán egy kertészetből származó földdel terítették be a munkaterületet. Ezen a kb. 100 m-es sávon jelent meg mintegy 10 tő útifúlevelű kígyószisz (Echium plantagineum) elszórva. A sáv melletti taposott, régebben vetett gyepben található a következő jellemző fajokkal: Plantago lanceolata, Achillea millefolium s.l, Convolvulus arvensis, Erodium cicutarium, Lolium perenne, Medicago lupulina, Oxalis dillenii, Podospermum canum, Polygonum aviculare, Taraxacum officinale, Trifolium pratense, Trifolium repens. A munkaterület sávjában szórványosan ezek a fajok jelentek meg az útifúlevelű kígyószisz mellett. Az állományból több példányt begyűjtöttünk herbáriumi dokumentálás céljából és eljuttatuk azokat a MTM Növénytárába (HNHM-TRA 00128780, HNHM-TRA 00128781), valamint a Debreceni Egyetem Herbáriumába (DE-Soo-48341). 2021-es évben itt sem jelent meg újabb egyede a fajnak.

\section{Megvitatás}

Jelenlegi helyzete hazánkban

Az útifűlevelű kígyószisz (Echium plantagineum) tőlünk délre őshonos, gyakori faj. Európán kívül számos kontinensen megjelent, Ausztráliában özöngyomként tartják számon, tehát jelentős terjedési képességgel rendelkezik és képes az invázióra. Felbukkanása hazánkban sem meglepő. Az enyhülő telek, különösen városi viszonyok közt lehetőséget teremtenek a túlélésére és akár önfenntartó populációk kialakulására. Emiatt javasoljuk a faj beillesztését az aktuális határozókulcsba (KIRÁLY, 2009) az alábbi módon (k. = kígyószisz):

1a A párta fehér vagy fehéreslila.

E. italicum L. - Magas k.

1b A párta kék v. vörös (ritkán fehér). 2

2a A párta piros v. vörös, csöve hosszabb a csészénél. A bibe csúcsa ép.

E. maculatum L. - Piros k.

2b A párta kék, csöve rövidebb a csészénél. A bibe csúcsa kéthasábú 3

3a A párta világoskék, a szirom (10-)15-20 mm hosszú. A pártán 4 porzó túlnyúlik. A tőlevelek lándzsás-hosszúkásak. A virágzat nem ágazik el.

E. vulgare L. - Terjőke k.

3b A párta eleinte bíboros, később kék színű, a szirom 18-30 mm hosszú, melyen csak 2 porzó nyúlik túl. A tőlevelek széles-tojásdadok, nyelesek. A felső szárlevelek szíves vállúak. A virágzat elágazó, terebélyes is lehet. T: 20-60(-200) cm. Th(-HT). V-VI. Adv. (Medit). Szarvas, Budapest. Zavart gyepek, ruderális élőhelyek.

E. plantagineum L. - Útifúlevelủ k.

\section{Invázió és természetvédelmi vonatkozások}

Különösen tanulságos a faj szarvasi állományának előkerülése, hiszen itt a növény betelepülését azonnal „tetten érte” egy botanikus [8]. A növény példányai a kertnek azon részéről kerül- 
tek elő, ahol a személygépkocsi gumiszőnyegeit, strandfelszerelést és a cipőket szokták a kerti csapnál lemosni, ezért egyértelműnek tűnik a behurcolás módja. A szerző az utóbbi években többször járt mediterrán területeken, pl. Olaszország, Horvátország, Montenegró, Görögország, így ezek lehetnek a magok lehetséges származási területei. Ez a jól dokumentált behurcolás arra példa, hogy az utazások alkalmával könnyen kerülnek be új fajok - például a mediterrán területekről - Magyarországra (FEKETE et al. 2018, LUKÁCS \& VALKó 2018), és a klímaváltozás kedvez a mediterrán fajok megtelepedésének és meghonosodásának (pl. Wolf \& KIRÁLY 2014, BALOGH \& MESTERHÁZY 2017, TAKÁCS et al. 2020, WIRTH \& CSIKY 2020, WIRTH et al. 2020).

A klímaváltozás, illetve a globális kereskedelem és közlekedés fejlődésével egyre több faj megjelenése várható olyan területeken, ahol azok addig nem voltak jelen (SEEBENS et al. 2016). Ezekből az újonnan megjelenő fajokból nem feltétlenül lesz mindenhol inváziós faj. Ennek előrejelzése nehéz, bár vannak javaslatok arra, hogyan lehet erre kockázatelemzést végezni (pl. GORDON et al. 2010). Továbbá egyes vizsgálatok arra engednek következtetni, hogy a földrajzilag közelebbi területekről származó fajok kevésbé válnak invázióssá (EssL et al. 2019), de ez nem minden faj esetén törvényszerü.

A faj a kifejlődéséhez enyhe, de csapadékos telet igényel. Budapesten a leghidegebb hónapban, januárban az átlagos csapadék $34 \mathrm{~mm}$, míg az átlagos középhőmérséklet $0,6{ }^{\circ} \mathrm{C}$, de ez 6,2 és $-4,02{ }^{\circ} \mathrm{C}$ közt változhat (OMSZ [9]). Azaz enyhébb teleken megfelel a MoorE (1967) által jelzett leghidegebb hónapra vonatkozó értékeknek. Ez alapján elmondhatjuk, hogy a faj éghajlattal szembeni igénye egyes években teljesül és ezt a városi környezet hőmérsékletnövelő hatása csak még jobban kielégíti. Általánosan ismert, hogy a közlekedés és a melegebb városi klíma együttesen növelik a neofiton növényfajok számát a városokban (VoN DER LIPPE et al. 2005, KüHN et al. 2017). Ugyanakkor nem biztos, hogy a megtelepedő neofiton fajokből inváziós fajok lesznek, így az útifűlevelű kígyószisz esetén sem egyértelmű, hogy az alkalmi megtelepedő fajból inváziós faj lesz-e hazánkban. Amennyiben a téli átlagos minimumhőmérséklet tartósan növekszik, akkor megnő a lehetősége ennek.

\section{Közösségi kutatások értékelése}

A faj előfordulásáról egy közösségi oldal növényhatározás céljából szerveződő csoportjában szereztünk tudomást. Hazánkra új - akár növény-, állat- vagy gomba- - faj feltűnése nem egyedi a közösségi oldalakon, különösen az adott témák, fajcsoportok köré szerveződő csoportokban. De ez csak szelete azoknak a lehetőségeknek, amelyek segítségével a nem hivatásos kutatók bevonhatók egy adott terület, pl. egy ország élővilágának megismerésébe. Erre számos és egyre bővülő lehetőség adódik. A közösségi oldalakon keresztül kapcsolatba kerülhetnek a hivatásos biológusok és a civil természetjárók, természetbúvárok, majd akár ezen online csoportokon keresztül, akár ettől függetlenül rögzíteni lehet a fajelőfordulásadatokat. Az adott fajcsoport szakértői által ellenőrzött internetes felület, honlap lehetőséget ad a nagyobb térbeli kiterjedésű adatgyűjtésre. Ilyen felület például az országos kétéltű- és hüllőtérképezés céljából létrehozott Herptérkép [2] vagy Magyarország Flóratérképezési Adatbázisa [3]. Számos kezdeményezést fog össze az OpenBiomaps [10]. A most bemutatott növényfaj megtalálásának története is jól mutatja, hogy a tematikus csoportok segítségével egy-egy élőlénycsoport jelenlétéről, elterjedési területéről sokkal több és nagyobb földrajzi lefedettségü adatot lehet gyüjteni, így ezeknek a csoportoknak a múködését mindenképpen érdemes figyelemmel kísérni, támogatni.

\section{Köszönetnyilvánítás}

Ezúton is szeretnénk kifejezni köszönetünket Waldmann Katalinnak, aki megtalálta a faj budapesti állományát és megmutatta nekünk a lelőhelyet. Köszönjük Takács Attilának és Bauer 
Norbertnek a herbáriumi példányok kezelését, Nejc Jogannak és Barina Zoltánnak pedig a faj balkáni előfordulásával kapcsolatos ismeretek megosztását. A kutatást a FK-NKFIH 128465 pályázat támogatta.

\section{Irodalom}

BALOGH L., DANCZA I. \& KIRÁLY G. (2004): A magyarországi neofitonok időszerű jegyzéke, és besorolásuk inváziós szempontból. - In: MıнÁLY B. \& BoTTA-DuKÁT Z. (szerk.): Biológiai inváziók Magyarországon. Özönnövények. A KvVM Természetvédelmi Hivatalának Tanulmánykötetei, 9, TermészetBúvár Alapítvány Kiadó, Budapest, pp. 61-92.

BALOgh L. \& MESTERHÁZY A. (2017): Két új adventív faj előfordulása Magyarországon a buzérfélék (Rubiaceae) családjából. - Kitaibelia 22: 286-296.

BURDON J. J., JAROSZ A. M. \& Brown A. H. D. (1988): Temporal patterns of reproduction and outcrossing in weedy populations of Echium plantagineum. - Biological Journal of the Linnean Society 34(1): 81-92.

CULLEN J. M. \& Delfosse E. S. (1984): Echium plantagineum: catalyst for conflict and change in Australia. - In: Proceedings of the VI international symposium on biological control of weeds. Ottawa, Canada: Agriculture Canada, pp. 19-25.

essl F., Dullinger S., Genovesi P., Hulme P. E., Jeschke J. M., Katsanevakis S., ... \& Bacher S. (2019): A conceptual framework for range-expanding species that track human-induced environmental change. - BioScience 69(11): 908-919.

FeKete R., Mesterházy A., VAlKó O. \& Molnár V. A. (2018): A hitchhiker from the beach: Th e spread of the maritime halophyte Cochleria danica along salted continetal roads. - Preslia 90(1): 23-37.

FERNÁNDEZ AlÉs R, LAFFARGA J. M. \& ORTEGA F. (1993): Strategies in Mediterranean grassland annuals in relation to stress and disturbance. - Journal of Vegetation Science 4: 313-322.

FILARSZKY N. (1894): Adatok Budapest flórájához. - Pótfüzetek a Természettudományi Közlönyhöz 26: 117-121.

Gordon D. R., Mitterdorfer B., Pheloung P. C., Ansari S., Buddenhagen C., Chimera C., ... \& Williams P. A. (2010): Guidance for addressing the Australian weed risk assessment questions. - Plant Protection Quarterly 25(2): 56.

Grigulis K., SheppaRd A. W., ASH J. E. \& GRoves R. H. (2001): The comparative demography of the pasture weed Echium plantagineum between its native and invaded ranges. - Journal of Applied Ecology 38(2): 281-290.

Holm L., PANCho J. V., Herberger J. P. \& Plucknett D. L. (1979): A geographical atlas of world weeds. - John Wiley and Sons, New York, Chichester, Brisbane, Toronto, UK.

HulmE P. E. (2009): Trade, transport and trouble: managing invasive species pathways in an era of globalization. - Journal of Applied Ecology 46(1): 10-18.

JoGAn N. (ed.) (2001): Gradivo za atlas flore Slovenije [Materials for the atlas of flora of Slovenia]. Center za kartografijo favne in flore, Miklavž na Dravskem polju.

KIRÁlY G. (ed.) (2009): Új Magyar Füvészkönyv. Magyarország hajtásos növényei. - Jósvafö, Aggteleki Nemzeti Park Igazgatóság.

KüHN I., Wolf J. \& SCHNEIDER A. (2017): Is there an urban effect in alien plant invasions? - Biological Invasions 19(12): 3505-3513.

LUKÁCS K. \& VALKó O. (2018): A ruházat szerepe az ember általi magterjesztésben. - Kitaibelia 23(1): 77-86.

Moore R. M. (1967): The naturalization of alien plants in Australia. - In: Proceedings and Papers IUCN 10th Technical Meeting, Part III, section 1, Lucerne Switzerland, pp. 82-97.

NOY-MeIR I., GUTMAN M. \& KAPLAN Y. (1989): Responses of Mediterranean grassland plants to grazing and protection. - Journal of Ecology 77: 290-310.

Piggin C. M. \& Sheppard A. W. (1995): Echium plantagineum - In: Groves R. H., Shepherd R. C. H. \& RichaRdson R. G. (eds), The biology of Australian weeds. Volume 1. Richardson, Melbourne, Victoria, Australia, pp. 87-110.

PyšEk P., DANihElKa J., SÁDlo J., Chrtek J. Jr., ChytrÝ M., JARošík V., ... \& TichÝ L. (2012): Catalogue of alien plants of the Czech Republic: checklist update, taxonomic diversity and invasion patterns. - Preslia 84(2): 155-255.

Seebens H., Blackburn T. M., Dyer E. E., Genovesi P., Hulme P. E., JeschKe J. M., ... \& Essl F. (2017): No saturation in the accumulation of alien species worldwide. - Nature Communications 8(1): 1-9. 
Seebens H., Essl F., Dawson W., Fuentes N., Moser D., Pergl J., ... \& Blasius B. (2015): Global trade will accelerate plant invasions in emerging economies under climate change. - Global Change Biology 21(11): 4128-4140.

Shea K., Smyth M., Sheppard A., Morton R. \& Chalimbaud J. (2000): Effect of patch size and plant density of Paterson's curse (Echium plantagineum) on the oviposition of a specialist weevil, Mogulones larvatus. - Oecologia 124(4): 615-621.

SHEPPARD A. W. \& SMYTH M. (2012): Echium plantagineum L. - Paterson's curse. - In: Julien M., McFAdyen R. \& Cullen J. (eds), Biological Control of Weeds in Australia. CSIRO Publishing, Collingwood, Victoria, pp. 211-226.

SMYTH M. J., MoORHouSE J., ShePpard A. W. \& SWirepik A. (1992): Factors affecting the dominance of Echium plantagineum in annual pastures. - Australian Weed Research Newsletter 20: 11-14.

SMYTh M. J., SHEPpard A. W. \& SwirepiK A. (1997): The effect of grazing on seed production in Echium plantagineum L. - Weed Research 37: 63-70.

Takács A., Wirth T., SchmotZer A., Gulyás G., Jordán S., SÜveges K. \& Somlyay L. (2020): Cardamine occulta Hornem. Magyarországon, és a dísznövénykereskedelem más potyautasai. - Kitaibelia 25(2): 195-214.

VON DER LIPPE M., SAUMEL I. \& KOWARIK I. (2005): Cities as drivers for biological invasions - the role of urban climate and traffic. - ERDE-BERLIN 136(2): 123.

WiRTH T. KovÁCS D. \& CsiKY J. (2020): Adatok és kiegészítések a magyarországi adventív flóra kivadult, meghonosodott és potenciális inváziós fajainak ismeretéhez. - Kitaibelia 25(2): 111-156.

WirTh T. \& CSIKY J. (2020): Contributions to the Hungarian alien flora: Erigeron bonariensis L. and $E$. sumatrensis Retz. (Asteraceae) in Hungary. - Botanikai Közlemények 107(1): 33-43.

Wolf M. \& KiRÁly G. (2014): Euphorbia serpens (Euphorbiaceae), a new alien species in Hungary. - Acta Botanica Hungarica 56(1-2): 243-250.

\section{Világháló-oldalak}

[1] Vadonleső program - https://vadonleső.hu/ (Hozzáférés: 2021.02.24.)

[2] Herptérkép - https://herpterkep.mme.hu/ (Hozzáférés: 2021.02.24.)

[3] Magyarország Flóratérképezési Adatbázisa - https://floraatlasz.uni-sopron.hu/ (Hozzáférés: 2021.02.24.)

[4] USDA - United States Department of Agriculture - https://npgsweb.arsgrin.gov/gringlobal/taxon/taxonomydetail?id=14875 (Hozzáférés: 2021.02.25.)

[5] CABI - Invasive Species Compendium https://www.cabi.org/isc/datasheet/20400\#tosummaryOfInvasiveness, https://www.cabi.org/isc/datasheet/20400\#toreferences (Hozzáférés: 2021.02.25.)

[6] The Euro+Med PlantBase - the information resource for Euro-Mediterranean plant diversity http://ww2.bgbm.org/EuroPlusMed/PTaxonDetail.asp?NameCache=Echium\%20plantagineum (Hozzáférés: 2021.02.25.)

[7] Flora Croatica Database - https://hirc.botanic.hr/fcd/DetaljiFrame.aspx?IdVrste=3771\&taxon= Echium plantagineum L\&fbclid=IwAR0xWhiixOgOE-nIDOyrUPX9oJidlDpUyv5dVBDe4FYne2TAMTWERXZwlk (Hozzáférés: 2021.06.15.)

[8] https://www.newjsag.hu/2020/06/11/tetten-ert-zold-bevandorlo-szarvason

[9] OMSZ - https://www.met.hu/eghajlat/magyarorszag_eghajlata/varosok_jellemzoi/Budapest/ (Hozzáférés: 2021.06.15.)

[10] OpenBiomaps - https://openbiomaps.org/ (Hozzáférés: 2021.02.25.)

Beérkezett / received: 2021. 03.17. • Elfogadva / accepted: 2021. 06. 29.

\section{Elektronikus melléklet}

1. ábra Echium plantagineum habitusképe (Waldmann Katalin felvétele)

Fig. 1 Habit of Echium plantagineum (photo by Katalin Waldmann)

2. ábra Echium plantagineum virága (Jakab Gusztáv felvétele)

Fig. 2 Flower of Echium plantagineum (photo by Gusztáv Jakab)

3. ábra Echium plantagineum virágzata (Csecserits Anikó felvétele)

Fig. 3 Inflorescence of Echium plantagineum (photo by Anikó Csecserits) 
CSECSERITS A., JAKAB G. \& RÉDEI T. (2021):

Új adventív faj Magyarország flórájában: az útifúlevelú kígyószisz (Echium plantagineum) / The purple viper's bugloss (Echium plantagineum), a new adventive species for Hungary

Kitaibelia 26(2): 199-206.

DOI: $10.17542 /$ kit.26.199

\section{Elektronikus melléklet / Electronic appendix}

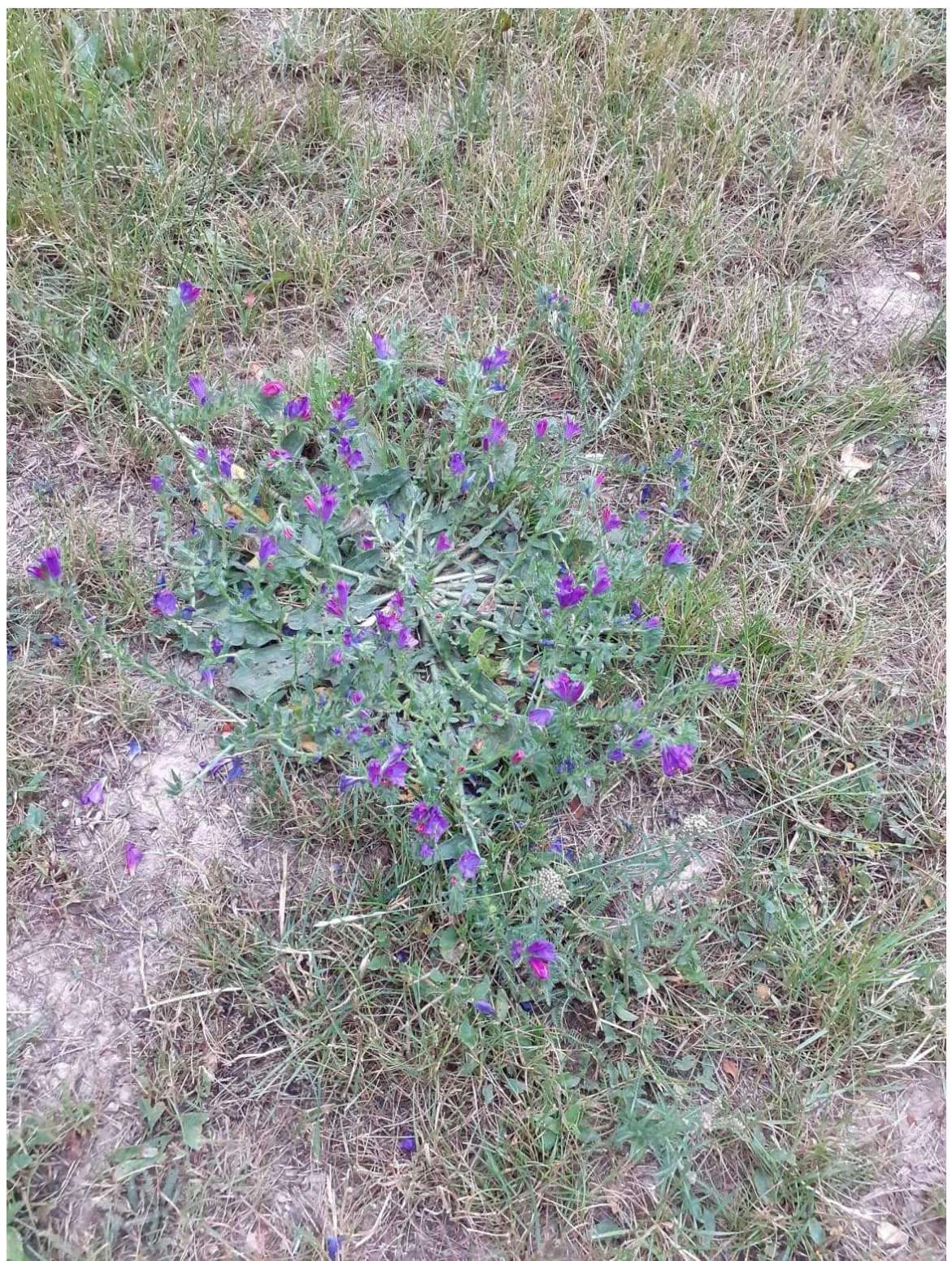

1. ábra Echium plantagineum habitusképe (Waldmann Katalin felvétele) Fig. 1 Habit of Echium plantagineum (photo by Katalin Waldmann) 


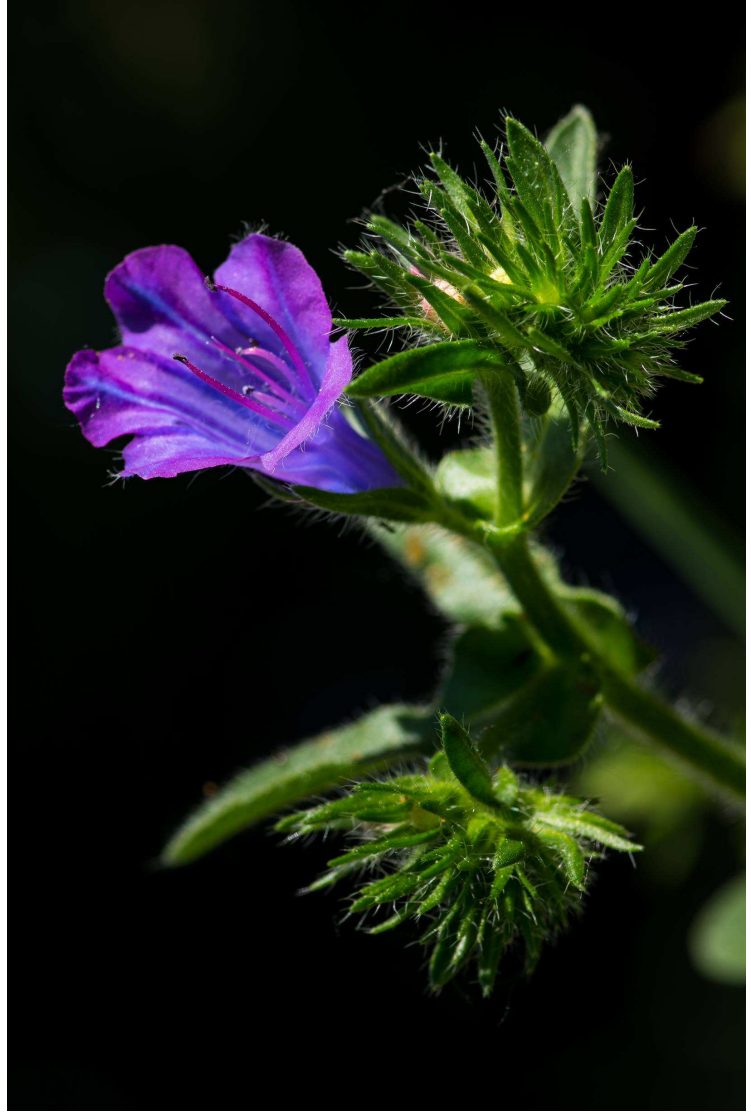

2. ábra Echium plantagineum virága (Jakab Gusztáv felvétele)

Fig. 2 Flower of Echium plantagineum (photo by Gusztáv Jakab)

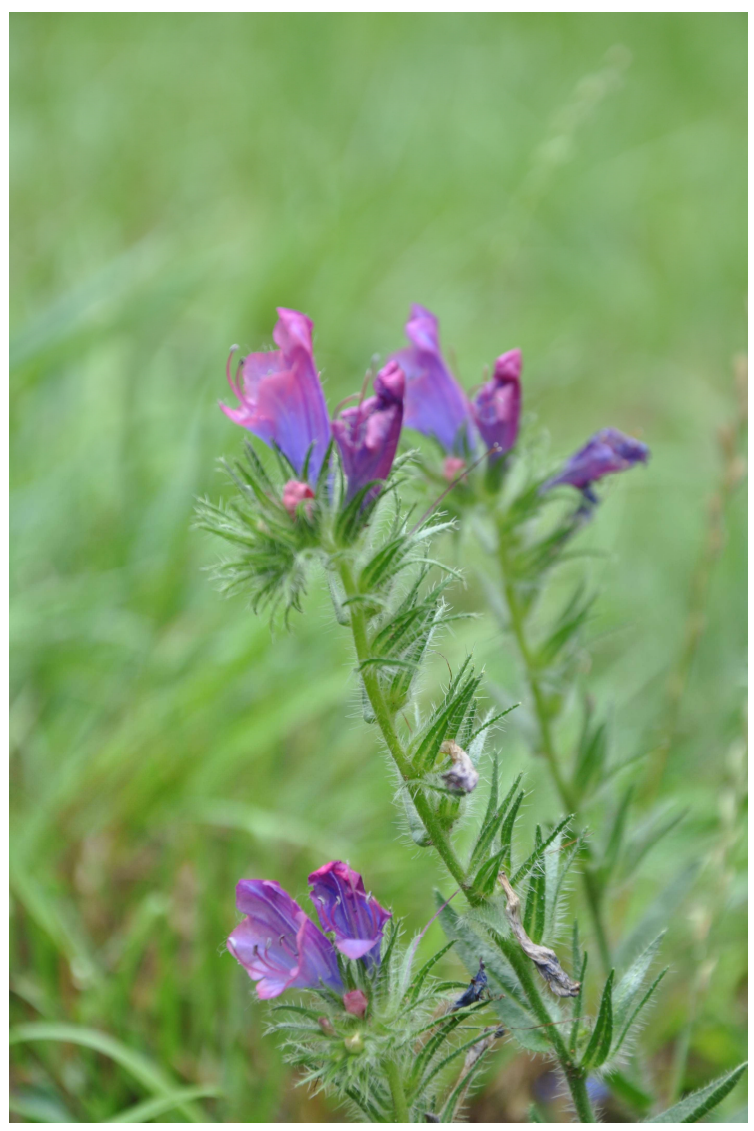

3. ábra Echium plantagineum virágzata (Csecserits Anikó felvétele)

Fig. 3 Inflorescence of Echium plantagineum (photo by Anikó Csecserits) 